\title{
Smuggling of human beings and connection with organized crime
}

\author{
Dr.Sc. Xhevdet Halili, PhD
}

Faculty of Law, University of Prishtina, Kosovo

\section{Abstract}

Through this paper is intended to note the difference between human smuggling and trafficking in human beings, emphasizing the distinctive items and those that are common. During work the focus is on criminal offenses committed by persons individually or as part of an organized crime group with particular focus on Kosovo.

During work addressed the causes or factors that have a direct or indirect impact on the reporting of crimes of immigrant smuggling as individual criminal acts or even when they are carried out in the form of organized crime.

By then treated roads that are used by smugglers in the case of smuggling of migrants to countries of Western Europe and the methods that they use to smugglers illegally crossed from one state to another state.

The paper also finally contains conclusions and recommendations for the prevention and combating criminal acts of persons smuggling.

Keywords: human smuggling; human trafficking; forgery of documents; organized crime; investigations; criminal sanctions; the Criminal Code of Kosovo

\section{Introduction}

The issue of smuggling of human beings first appeared historical aspect with the appearance of the borders between states, because as it is known from the definition of the offense of smuggling of human beings this is done in the case of illegal crossing of boundaries from one place to another or certain persons staying in a place without fulfilling the necessary conditions to stay in that state.

Combating and preventing criminal offense of smuggling of human beings, it is almost impossible without the cooperation of the police of the respective states, the fact that the combating and prevention of this offense is more closely associated with police work.

But in practice it often happens that the offense of smuggling of human beings carried out by organized crime groups, this fact even more difficult for the organs of prosecution for the purpose of investigation, detection and lighting of these offenses. 
The number of offenses of smuggling of human beings in Kosovo, is different and varies from year to year, while the number of cases initiated by the police is smaller than the number of persons convicted by the competent courts is understandable.

The offenses of this nature tend to increase especially in recent years in Kosovo, and the most common factors considered is the difficult economic situation and the high level of unemployment in the country.

\section{The problem of smuggling of human beings}

At the outset it should be emphasized that there is a fundamental difference between human smuggling and human trafficking. Smuggling of persons is an issue of grave concern, especially assistance in smuggling is a permanent problem in member states of the European Union (EU), as the list of persons wishing to enter illegally in EU countries, is endless. ${ }^{1}$ The social, economic and political life of smuggling will be among the most serious concerns for the EU today but also in future years.

The smuggling of human beings, but also help illegal immigrants has increased worldwide. The problem is aggravated many and serious, with the increased involvement of organized crime groups and the emergence of trends "combinations" of some regions traditional organized crime.

What is important to note, the methods by which smuggled illegal immigrants in the EU countries, often differ by region of origin. This means that there is a similar attitude among illegal immigrants from the same region, who tend to use assistants with the same ethnicity. ${ }^{2}$ Such a form of organized crime is conditioned by several factors and circumstances, such as conflicts of a political, ethnic, cultural, religious, various wars, misery, poverty and various disasters, which conditions push many people to flee their homes and take the road to the richest countries and safer. ${ }^{3}$ The emergence of this form of criminality have influenced persecution and systematic violations of freedoms and human rights and pursued numerous crimes against certain ethnic groups, religious, cultural etc.

As a consequence of such a climate that is created in some countries, but is increasing more and more the number of persons who have entered the developed countries, whether in the capacity of asylum seekers even if other persons. Such a situation course that suits most organized criminal groups, which often make illegal trafficking of these persons, earning large sums of money. Also, it is evident that organized crime groups, are directed and controlled market looking further profits, encouraging people

\footnotetext{
${ }^{1}$ Ismet Elezi, Bejko Shefki, Overview of the development of the Albanian legislation against organized crime, Tirana, 2002, p. 10 ${ }^{2}$ Ibid.
}

${ }^{3}$ Gashi,Rexhep, Organized Crime, Prishtinë, 2011, p. 23. 
who for various reasons do not intend to immigrate, to pay amounts great to do such a thing. ${ }^{4}$

Largely organized crime groups that help illegal immigration, can be found in the ethnic communities that are already present in European Union member states, this can be seen as an attractive factor of incentive. It is well known that different groups of organized crime often cooperate with each other, especially in the movement of goods across borders between countries. This cooperation has already expanded into new member states of the EU and the planning of EU enlargement, is likely to create opportunities for organized crime groups to seek new markets and simultaneously benefit criminal new territories, of which will organize their criminal activities in connection with smuggling of persons.

\section{The definition of the offense of smuggling of human beings}

Within the Criminal Code of Kosovo in force, clearly defined the smuggling of immigrants, which says: Smuggling of immigrants means benefit, direct or indirect financial benefit or other material benefit, producing, supplying, providing or possessing documents fraudulent travel or identity. ${ }^{5}$ For committing the offense of smuggling of immigrants, as a special criminal offense, but also the acts performed as part of the organized crime group, the policy provided stiff penalties. Meanwhile, its application in practice is not yet satisfactory. However, we believe that, with the consolidation of institutions that deal with law enforcement in Kosovo, this problem will be solved. Naturally, smuggling and human trafficking are interrelated, especially when they are committed criminal acts, within the activities of organized crime. However, they differ in essence, because the smuggling of human beings intended to just pass people from one country to another, avoiding the regular points of administrative control and customs, or without possessing the necessary documents to pass or to stay in the country of destination.

In general, we can say that any smuggling route, which is used by illegal immigrants, aimed at EU countries, involves a certain distance, starting from the source, outside the EU countries, and ending in the destination country within the EU states, in most cases using the transit countries during their trip to Western countries. ${ }^{6}$

\section{Some of the routes used for smuggling of human beings}

As a result of the identification and exploitation of weaknesses in the existing regimes to control immigration by organized crime groups have developed some favorable

\footnotetext{
${ }^{4}$ Elezi, Bejko, op. cit., p. 10.

${ }^{5}$ Article 170, paragraph 2, of the Criminal Code of Kosova.

${ }^{6}$ Togal Oguz, Mehmet: Organized Crime, Istanbul, 2006, p. 27
} 
route, through which the smuggling of human beings, which can be recognized as follows:

- Eastern Mediterranean route;

- Way of North Africa;

- Balkan route;

- The way the West African Atlantic coast;

- Path of Central and Eastern Europe;

- Baltic route. ${ }^{7}$

The street of North Africa is seen as a way to carry the largest number of illegal immigrants in the EU countries. Road Central and Eastern Europe is getting increasing importance, while the importance of the Baltic route has declined and is ready to be considered as a common path. These are relatively fixed along the way, where are available several opportunities and services (for example: shelter, illegal border crossings, transport terminals, etc.). Street geographical and transportation means between the connection points can vary widely, but mainly connecting points remain constant or unchanged. ${ }^{8}$ However, what is more important, three transit countries, countries that mostly used before reaching the external borders of the EU, are: Russia (Moscow), Ukraine (Kiev) and Turkey (Istanbul). These are used either as a point of departure or as a focal point to continue on towards the EU states. In addition, the Balkans (Sarajevo and Belgrade) is still considered as regions that are used largely for travel from outside EU countries. Also, North Africa, p.sh: from Morocco to Spain, from Tunisia and Libya to Italy etc. ${ }^{9}$ Besides these roads, illegal immigrants, especially from remote sites, also use air directly to the EU states. Joint European wide operations, most of them supported by Europol, have discovered that European international airports are some of the key nodes for illegal entry. Twin elements of international air links which are continually expanding and lower prices, offer many different opportunities transit to reach their final destinations, which greatly misused by aides illegal immigration or smuggling. Therefore, global air traffic routes should be considered when it comes to roads to EU countries. ${ }^{10}$

Therefore, prevention and combating smuggling of human beings, as a form of organized crime, without the cooperation between different states, it is impossible to tell. A good case in point, of this nature, was the cooperation between the police of EULEX and Kosovo police, who took part in January 2013 in a international press conference in Budapest, which is presented successful completion of a large-scale

\footnotetext{
${ }^{7}$ lbid.

${ }^{8}$ Ibid., p. 28.

${ }^{9}$ Ibid.

${ }^{10}$ Ibid.
} 
operation in Europe, connected to the smuggling of migrants by: Syria, Lebanon and Turkey to Western Europe. ${ }^{11}$ This collaboration was made possible on the basis of intelligence and information provided by EULEX. During the operation, which took place simultaneously in 10 countries, 103 people have been arrested and are conducted 117 raids. Such a contribution Police EULEX and Kosovo police was not recorded earlier regarding such extensive surgery, which ended successfully. ${ }^{12}$ According to the same source, but also based on police reports, with respect to this case, some of the key leaders of this transnational criminal network had operated from Kosovo, which served as a transit route from Syria, Lebanon and Turkey to Western European countries. The so-called "Fimathu" was conducted under the auspices of Europol and included cooperation with Kosovo, Montenegro, Hungary, Bosnia and Herzegovina, Austria, Italy, Slovenia, Croatia, France, Germany, Greece, Czech Republic and Slovakia. In Kosovo, the case was investigated by a EULEX prosecutor from the Kosovo Special Prosecution. ${ }^{13}$

\section{Some of preparatory actions for the smuggling of human beings}

Smugglers in most cases should regulate falsified documents, in order to realize their goals. Among the most common methods, and simple, to enter the EU Member States, must be through the people hiding in vehicles. However, improvement of border checks has increased the use of counterfeit documents with higher and more sophisticated.

The fraudulent or modified is more likely to appear at seaports and airports, where controlled documents unchanged. Meanwhile, total quality forged documents has reached a high level, so it is nearly impossible to observe forgeries by more experienced staff, which explains forged documents can appear anywhere and at any time. ${ }^{14}$ Most illegal immigrants entering Western countries do not possess the original identity documents. Criminal groups, or said differently networks aides also assist illegal immigrants in supplying forged travel documents (forged, stolen or altered) to hide the true identity of the persons smuggled. ${ }^{15}$

In most cases aides turn back forged documents to reuse later for other people who are smuggled to the same countries of destination. From the literature, but also from the practice, known cases criminal networks receive targeted embassies and consulates to obtain travel documents, allegedly for legal business activities or through the sector for

\footnotetext{
${ }^{11}$ For more information see: http://www.gazetaexpress.com/?cid=1, 15, 102687; Included in the international operation in the fight against organized crime, (accessed date: 01.31. 2013).

12 Ibid.

13 Ibid.

${ }^{14}$ Togal, op. cit., p. 44.

${ }^{15}$ Report for Organized Crime, from Europol, 2000, p. 68.
} 
tourist trips. Visas issued happens sometimes based on forged documents (assuming that the documents are original), because smugglers make hotel reservations, make false invitations to participate in musical evenings, even being featured as singers etc.

One of the key problems today is the frequency of theft of blank passports and visas from consulates worldwide. ${ }^{16}$ Then these easily modified and illegal immigrants issued or given persons who engage in criminal purposes. The main types of documents used to help people smuggling include: passports, visas, residence permits etc. Different types of passports found include those that are completely false, they are changed (perhaps by replacing the photograph) and those which belong to another person with similar features. ${ }^{17}$ Visas, these are also false, as described above in the case of passports, but there are cases where visas are obtained through fraud. P.sh: appearing as a student or tourist. Permits therefore permit to stay and works are also the target of forgery. It is known that in many cases, immigrants, while seeking asylum in a Member State, they already possess a residence permit for another country. Even misuse of original documents (by fraudsters), or the so-called "likes", widely used, especially in some countries. ${ }^{18}$ Obviously that smugglers use other forms to perform their criminal activities, and especially when they undertake these actions as part of criminal groups organized, so we have highlighted just a few of the forms of documents that they falsify their purposes, but there are many other forms of forgery for the purpose of smuggling.

\section{The legislative base of smuggling of migrants in Kosovo}

The smuggling of migrants as a criminal offense provided for in Article 170, paragraph 1 of the CCK, which states: "Whoever deals with migrant smuggling punishable by a fine and imprisonment of two to ten years." In paragraph 2, states: "Whoever the purpose of obtaining direct or indirect financial benefit or other material benefit, produces, supplies, acquires or possesses false travel documents or identification for the purpose of enabling the smuggling of migrants, punishable by fine and imprisonment up to five years. "But also enable other people stay in Kosovo, who are not citizens of the country, could be a criminal offense under Article 170, paragraph 3 of the CCK, as follows:" Whoever enables a person who is not a citizen of the Republic of Kosovo to remain in Kosovo or person who is not a citizen or permanent resident to remain in the country in question without regard to the legal requirements necessary to stand with any other tools illegal, punishable by fine and imprisonment up to one year. "in paragraph 4 of Article 170 provides that the attempt is punishable, but only for foreigners who tend, like" attempt to commit this offense is punishable. "this offense

\footnotetext{
${ }^{16} \mathrm{lbid}$.

${ }^{17}$ Ibid.

18 Ibid.
} 
can be done in the form of organized crime, which is treated in his doctoral work, so in the CCK, Article 170, paragraph 5, provided severe penalties for this offense, when carried out in the form of organized crime, as follows: "Whoever organizes or directs other persons to commit the offense of this nature, punishable by a fine of up to 500,000 euro and by imprisonment of seven to twenty years, or with imprisonment of one to ten years for the offense of permitting other persons who are not citizens of our country. “

Also, Article 170, paragraph 6 and 7 of CCK also predicts where anyone can lose life, then provided these sentences, as follows: "Where the offense committed by the perpetrator acting as a member of the group or in a manner that endangers or is likely to endanger the lives or safety of the migrants concerned or that entails inhuman or degrading, including exploitation of such migrants, the perpetrator shall be punished by a fine and imprisonment of not less than five years". Or: "If the offense results in the death of one or more persons, the perpetrator shall be punished by a fine and imprisonment of at least ten years or life imprisonment." According to the definitions in the acts and conventions, the term "contraband" understands the direct use of mediation services, which deals with the organization and crossing international borders, avoiding the control of the border police and customs. ${ }^{19}$ Also, the smuggling of migrants understood as mediation to illegally enter a person in a state in which the person is not a citizen or permanent resident, for the purpose of a financial or other material benefit. ${ }^{20}$

Some statistical data on migrant smuggling in Kosovo during the period 2006-2010

Based on data provided for the period 2006-2010, were conducted a number of offenses, a total of 108 offenses, which are registered by the competent institutions, of which the following will be presented in tabular form.

The offense of smuggling of migrants

\begin{tabular}{|l|l|c|c|c|c|c|c|}
\hline No & Institution & $\mathbf{2 0 0 6}$ & $\mathbf{2 0 0 7}$ & $\mathbf{2 0 0 8}$ & $\mathbf{2 0 0 9}$ & $\mathbf{2 0 1 0}$ & Total \\
\hline 1. & Initiation by police & - & 34 & 21 & 27 & 26 & 108 \\
\hline 2. & Court decisions & 25 & 17 & 12 & 20 & 18 & 92 \\
\hline
\end{tabular}

Table 1. Smuggling of migrants in Kosovo during 2006-2010 ${ }^{21}$

For 2006 we have a lack of data, because in that period of time keeping and data system has been the responsibility of UNMIK police. In 2007, the entire territories of

\footnotetext{
${ }^{19}$ Article 3, Protocol against the Smuggling of Migrants by Land, Sea and Air.

${ }^{20}$ Article 7, United Nations, Convention against transnational organized crime.

${ }^{21}$ Police Information System of Kosovo (KPSI), (get on date: 05.07.2011).
} 
the Republic of Kosovo are carried out in total 34 cases of offense smuggle of migrants. However, in 2008 there was a decrease of registered cases of criminal smuggling of migrants in the whole territory of the Republic of Kosovo, with total registered 21 offenses of this nature. It is characteristic that in 2008 there is reduction in the number criminal offenses. When compared with 2007 to 2008 there was a decrease of 13 cases less. In 2009 the number of offenses committed starts to rise again within the 12-month period, and throughout the country carried out a total of 27 cases of crime, smuggling of migrants. Following year (2010), however, marks a stagnation of offenses that are committed in the Republic of Kosovo, wherein a less offense of this nature, compared with the previous year, i.e. in 2010, carried a total of 26 cases of this offense.

When analyzing the data provided on the decisions taken by the competent courts for offenses of smuggling of migrants for the period 2006-2010, in Kosovo, as shown by these statistics, in 2006 convicted 25 people, in 2007 convicted 17 people, in 200812 people were convicted in 2009 were convicted 20 people, and in 2010 sentenced 18 persons. So, in total over the past five years been convicted 92 persons.

\section{Conclusions}

Although in some countries treated as, A, there is a fundamental difference between human smuggling and human trafficking.

Punitive policy against offenders of human smuggling is tough, but its implementation in practice, is not sufficiently satisfactory.

Joint European-wide operations, most of them supported by Europol, have discovered that European international airports are some of the key nodes for illegal entry.

Preventing and combating smuggling of human beings, as a form of organized crime, without the cooperation between different states, it is impossible to tell.

The main types and falsified documents used to help people smuggling include: passports, visas, residence permits etc.

Relying on statistical data in Kosovo note that the number of cases to which initiated investigations and to those cases that are imposed criminal sanctions, is directly proportional to and in accordance with international norms to combat this phenomenon. 


\section{Bibliography}

1. Ismet Elezi, Bejko Shefki, Overview of the development of the Albanian legislation against organized crime, Tirana, 2002.

2. Gashi, Rexhep, Organized crime, Prishtina, 2011.

3. Criminal Code of Kosovo, 2013.

4. Togal Oguz, Mehmet: Organized Crime, Istanbul, 2006.

5. Report for Organized Crime, from Europol, 2000.

6. Protocol against the Smuggling of Migrants by Land, Sea and Air.

7. UN Convention against organized crime.

8. Information System Kosovo Police (KPIS), (get on date: 05.07.2011).

9. For more information see: http://www.gazetaexpress.com/?cid=1, 15, 102687; Included in the international operation in the fight against organized crime, (accessed date: 01.31. 2013). 